DOI:

Світлана Стеблюк, кандидат педагогічних наук Мукачівського кооперативного торговельно-економічного коледжу

\title{
ПІДГОТОВКА МАГІСТРІВ 3 ПІДПРИСМНИЦТВА, ТОРГІВЛІ ТА БІРЖОВОЇ ДІЯЛЬНОСТІ У КОНТЕКСТІ СТУПЕНЕВОЇ ОСВІТИ
}

У статті розкрито особливості підготовки магістрів зі спечіальності 076 Підприємництво, торгівля та біржова діяльність. Викладено актуальність дослідженої проблеми, щуо базується на окремих законодавчих актах в галузі освіти. 3'ясовано положення Концепиії підготовки магістрів в Украӥні, щзо стало основою у розробиі освітніх програм за названою спеціальністю. Розкрито окремі наукові дослідження щчодо проблем підготовки магістрів в сучасних реаліях; указано суперечності між готовністю до здійснення підприємницькоі діяльності і дослідницькою роботою в наукових установах. Автором проаналізовано освітні програми окремих закладів вищої освіти з підготовки магістрів до майбутньої професійної діяльності, науково-педагогічної зокрема. Закиентовано увагу на змісті їх теоретико-практичної підготовки.

Розроблено інновачійні методи викладання, серед яких: створення ситуацій емоційно-моральних переживань, конструктивний, моделювання, майндмеппінг, фішбоун.

Ключові слова: дослідницька діяльність; освітній ступінь “магістр”; освітня програма; ступенева освіта; фахова підготовка.

תim. 8.

Svitlana Steblyuk, Ph.D.(Pedagogy),

Mukachevo Cooperative Trade and Economic College

\section{TRAINING OF MASTERS IN ENTREPRENEURSHIP, TRADE AND EXCHANGE ACTIVITIES IN THE CONTEXT OF MULTI-DEGREE SYSTEM OF EDUCATION}

The article deals with the peculiarities of the training of masters of the specialty 076 Entrepreneurship, trade and exchange activities. The relevance of the investigated problem, which is based on separate legislative acts in the field of education, is described. The provisions of the Concept of the Master's Studies in Ukraine have been clarified, which became the basis for the development of educational programs of the named specialty. Separate scientific researches on problems of training of masters in modern realities are revealed. The contradiction between willingness to engage into entrepreneurship and research in scientific institutions is indicated. The purpose of the article is to find out the content of the educational programs of masters training in the specialty entrepreneurship, trade and exchange activities. The task is: to reveal the state of the problem under investigation in the scientific literature; to determine the peculiarities of their training for research (teaching) activity.

The author analyzes the educational programs of individual institutions of higher education for the training of masters for future professional activities, in particular, pedagogical. The emphasis is on the content of theoretical and practical training: the availability of discipline "Methodology of teaching disciplines on personnel management and labor economics" and pedagogical practice. It is determined, that pedagogical practice promotes the formation of skills of effective use of bases of such knowledge: the subject of teaching; psychology and pedagogy; teaching methods, goals, principles of teaching management; curricula, programs, textbooks, manuals, scientific and methodical literature, etc.

In the process of teaching the discipline "Technologies" module "Entrepreneurship" we developed innovative teaching methods. The effective ones are: creating situations of emotional and moral experiences, constructive, modeling, mindmapping, "fishbone".

The prospect of further research is to substantiate the model of the formation of professional competence among future specialists in entrepreneurship, trade and exchange activities.

Keywords: research activity; an educational degree "master"; an educational program; multi-degree system of education; professional training.

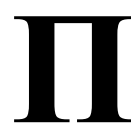

остановка проблеми. У Законі України “Про освіту” (Розділ 2, ст.10) сформульовано всі рівні освіти, серед яких: дошкільна освіта; початкова освіта; базова середня освіта; профільна середня освіта; перший (початковий) рівень професійної (професійнотехнічної) освіти, другий (базовий) рівень професійної (професійно-технічної) освіти; третій (вищий) рівень професійної (професійно-технічної) освіти, передвища освіта; перший (бакалаврський) рівень вищої освіти, другий (магістерський) рівень вищої освіти; третій (освітньо-науковий/освітньо-творчий) рівень вищої освіти; науковий рівень вищої освіти. Таким чином, 


\section{ПІДГОТОВКА МАГІСТРІВ З ПІДПРИЕМНИЦТВА, ТОРГІВЛІ ТА БІРЖОВОЇ ДІЯЛЬНОСТІ У КОНТЕКСТІСТУПЕНЕВОЇ ОСВІТИ}

сутність ступеневості вищої освіти полягає у іiі здобутті за ступенями: бакалавр - магістр доктор філософії - доктор наук [2]. Наказом Міністерства освіти і науки України №99 "Про Концепцію підготовки магістрів в Україні” від 10.02.2010 року передбачено наявність освітніх програм, які можуть бути поділені на:

- дослідницькі, що передбачають поглиблення досліджень в одній з наукових галузей;

- професійні, що передбачають розвиток професійних та формування управлінських компетенцій у певній галузі професійної діяльності;

- кар'єрні, що передбачають вдосконалення (просування) здобутих теоретичних знань i практичного досвіду для карјєрного зростання та підготовки до здійснення управлінської діяльності.

Важливість цього розподілу виходить із необхідності відділити підготовку майбутніх наукових і науково-педагогічних працівників, а також посилити практичну спрямованість професійних магістерських програм. За одним напрямом підготовки можуть існувати як дослідницькі, так і професійні освітні програми підготовки магістрів [3].

Основна увага нами закцентована на підготовці магістрів з підприємництва, торгівлі та біржової діяльності до майбутньої професійної діяльності. Проведений аналіз освітніх програм з означеної спеціальності дав можливість 3'ясувати, що закладами вищої освіти розроблено нормативні документи за вищевизначеними напрямами. Однак сьогодення потребує уваги до підготовки майбутніх фахівців до дослідницької діяльності, в тому числі викладацької. Готовність магістра передбачає наявних сформованих психологопедагогічних та методичних компетентностей.

Аналіз основних досліджень і публікацій. Означена проблема у центрі дослідження низки вчених. Проаналізуємо окремі наукові розвідки.

На думку О. Момот, практика сьогодення вказує на слабкий зв'язок між професійною підготовкою магістрів в університетах та сферою майбутньої педагогічної діяльності викладача вищого навчального закладу, а педагогічні вищі навчальні заклади акцентують увагу на підготовці шкільних учителів і не приділяють належної уваги підготовці викладачів для вищої школи. Університетська освіта нині є фундаментом прогресивного розвитку особистості та людства, а також інструментом підготовки сучасних науково-педагогічних працівників $[4,5]$.

Згідно Ліцензійних вимог провадження освітньої діяльності викладання у вишах здійснюється відповідно до кваліфікації освітнього працівника. Науково-педагогічні та наукові працівники, які здійснюють освітній процес, повинні мати стаж науково-педагогічної діяльності понад два роки та рівень наукової та професійної активності, який засвідчується виконанням не менше чотирьох видів та результатів 3 перелічених у пункті 30 Ліцензійних умов. Для другого (магістерського) рівня вищої освіти кадровий склад закладу освіти повинен включати з розрахунку на кожні десять здобувачів освітнього ступеня магістра одного викладача, який має кваліфікацію відповідно до спеціальності, науковий ступінь або вчене звання [8].

Виходячи з цього, науково-педагогічні працівники закладів економічної освіти, що готують до науково-дослідної роботи, в тому числі й магістрів $з$ підприємництва, торгівлі та біржової діяльності, повинні мати цілісну систему знань 3 педагогіки, психології, основ наукових досліджень, теорії та методик викладання. Ця думка підтверджується дослідженнями С. Погорілої, яка зазначає, що у процесі професійно-педагогічної діяльності магістр з економіки і підприємництва стикається з проблемами не тільки професійного, а й психолого-педагогічного характеру через відсутність теоретичної педагогічної бази щодо принципів, змісту, методів, прийомів та форм організації навчально-виховного процесу. Молодий викладач економічних дисциплін, який отримав основні знання під час навчання у вищому закладі освіти, потребує немало часу для адаптації до умов професійно-педагогічної діяльності, оскільки діюча система професійно-педагогічної підготовки не забезпечує належної готовності випускників магістратури до практичної педагогічної діяльності у ЗВО [7].

На думку В. Нагаєва, спочатку необхідно ознайомитися 3 основними психологічними концепціями формування пам'яті, знань, розумових дій та реальних вмінь. Процес формування знань у довгостроковій пам'яті людини включає ряд етапів: 1) сприйняття інформації; 2) розуміння суті питання; 3 ) запам'ятовування; 4) формування уміння застосувати вивчену ситуацію (наявність чіткого алгоритму); 5) формування навичок застосування теорії в конкретній практичній ситуації; 6) формування уміння самостійно застосувати знання в нетиповій ситуації; 7) формування уміння застосувати знання в нетипових ситуаціях в умовах обмеження інформації і ризику $[5,22]$.

Визначальними тенденціями розвитку світової освітньої системи стають поглиблення іiї фундаменталізації, посилення гуманістичної спрямованості, духовної та загальнокультурної складової освіти, формування у студентів 


\section{ПІДГОТОВКА МАГІСТРІВ 3 ПІДПРИЄМНИЦТВА, ТОРГІВЛІ ТА БІРЖОВОЇ ДІЯЛЬНОСТІ У КОНТЕКСТІСТУПЕНЕВОЇОСВІТИ}

системного підходу до аналізу складних технічних і соціальних ситуацій, стратегічного мислення, виховання соціальної та професійної мобільності [Там же, 3].

Мета статті. 3'ясувати зміст освітніх програм підготовки магістрів зі спеціальності Підприємництво, торгівля та біржова діяльність. Завдання: розкрити стан досліджуваної проблеми у науковій літературі; визначити особливості підготовки магістрів до дослідницької (викладацької) діяльності.

Виклад основного матеріалу дослідження. У процесі дослідження нами з'ясовувалися сучасні підходи до підготовки магістра $з$ підприємництва до майбутньої професійної діяльності. Вивчено освітні програми ОС “магістр” спеціальності 076 Підприємництво, торгівля та біржова діяльність більшості вишів (ДВНЗ “Ужгородський національний університет”, Львівський торговельно-економічний університет). 3'ясовано, що освітні програми відповідають сучасним вимогам, мають місце перелік дисциплін ("Регіональні особливості комерційної діяльності", “Економіка міжнародної інтеграціі”, “Паблік рилейшинз”, “Економіко-математичне моделювання світогосподарських процесів”), що відповідають сучасним вимогам підготовки фахівця в ринковому середовищі, європейському зокрема.

Освітня програма підготовки магістра в ДВНЗ "Ужгородський національний університет" за спеціальністю 076 Підприємництво, торгівля та біржова діяльність (спеціалізація Управління персоналом та економіка праці) передбачає вивчення курсу “Методика викладання дисциплін з управління персоналом та економіки праці” (94 кредити EKTS) та проходження педагогічної практики (6 кредитів EKTS), що дає широкі можливості майбутньому фахівцю реалізувати себе як у науково-дослідній, так і підприємницькій діяльності.

Розкриємо особливості проведення педагогічної практики за означеною спеціалізацією. Метою $є$ набуття студентами певних навичок і вмінь 3 основних напрямів викладацької діяльності. Самостійне опрацювання завдань практики повинно бути підгрунтям для засвоєння теоретичних знань 3 педагогіки та психології, методики викладання економіки, комунікацій у навчанні тощо на рівні їх застосування в реальних умовах життєдіяльності. Саме ці умови мають сприяти вихованню потреби у систематичному самовдосконаленні, без чого неможлива творча i натхненна праці. Педагогічна практика має сприяти формуванню навичок виконання таких функцій викладача: здійснювати теоретичну і практичну підготовку до викладання навчального предмета; планувати матеріал викладання; використовувати ефективні форми, методи та засоби навчання; сприяти становленню особистості; проводити індивідуальну роботу, постійно підвищувати свій професійний рівень, педагогічну майстерність, загальну культуру. Педагогічна практика має сприяти формуванню навичок ефективного використання основ таких знань: предмет викладання; психологія та педагогіка; методика викладання, цілі, принципи управління навчанням; навчальні плани, програми, підручники, посібники, наукова та методична література; індивідуальні характеристики тих, хто навчається; форми, методи та засоби навчальновиховного процесу; теорія і практика галузі; культура спілкування, його форми, способи, засоби.

Програмою практики передбачено виконання студентами низки завдань за певними етапами: розробляється загальна характеристика бази практики щодо основних аспектів економічної освіти; аналізується загальний кількісний склад тих, хто навчається і закріплений за базою практики; визначаються чинні навчальні плани та програми дисциплін, виконується аналіз навчальної літератури, методичного забезпечення навчання та дидактичних матеріалів; збирається психологічна інформація про особливості навчального контингенту (індивідуальнотипологічні та соціально-психологічні властивості). За погодженням 3 керівникамиконсультантами студенти відвідують та здійснюють критичний аналіз двох навчальних занять викладачів за певними параметрами: дидактичний матеріал, організаційний аспект заняття, організація поелементного засвоєння знань, індивідуальний підхід, раціональність використання часу тощо [6].

У процесі викладання методик закладаються дидактичні основи педагогічного процесу, розробляються завдання для самостійної (індивідуальної) роботи студентів, з'ясовуються традиційні та інноваційні методи навчання (викладання) економічних дисциплін. У процесі дослідження нами розроблено інноваційні методи навчання дисциплін економічного спрямування, що забезпечать якісну підготовку до науковопедагогічної діяльності. На нашу думку, ефективними методами $є$ :

- створення ситуацій емоційно-моральних переживань (вправа “Власна позиція”). Завдання: прокоментувати висловлювання відомих людей $\mathrm{i}$ обгрунтувати власне відношення до них: Гроші завдають найбільше неприємностей тоді, коли їх 


\section{ПІДГОТОВКА МАГІСТРІВ З ПІДПРИЕМНИЦТВА, ТОРГІВЛІ ТА БІРЖОВОЇ ДІЯЛЬНОСТІ У КОНТЕКСТІСТУПЕНЕВОЇОСВІТИ}

ділять (Е. Севрус). Уся перевага володіння грошима полягає в можливості користуватися ними (Б. Франклін);

- конструктивний (вправа "Відновіть втрачені дані”). Студентам пропонується таблиця 3 відсутніми даними, вони заповнюють їі 3 коментуванням;

- моделювання (завдання-ситуації). Необхідно дати відповідь на запитання ситуації, склавши діалог;

- майндмеппінг (ментальні карти). Це технологія візуалізації мислення і альтернативного запису;

- “фішбоун”. Це метод установлення причинно-наслідкових взаємозв’язків між об'єктом аналізу і впливаючими на нього факторами, вчинення обгрунтованого вибору. Застосування означеного методу дозволяє візуалізувати причинно-наслідковий зв'язок між економічними показниками; розподіляти етапи роботи за рівнем значущості. Алгоритм роботи:

- голова - тема, питання або проблема, яка підлягає аналізу;

2) верхні кістки основні поняття теми, причини виникнення проблеми;

3) нижні кістки - факти, що є підтвердженням певних причин понять;

4) хвіст - відповідь на поставлене питання, висновки.

Сьогодення потребує застосування інформаційнокомп'ютерних технологій, що дають можливість:

- створювати умови для реалізації індивідуального підходу в освітньомупроцесі, організації самостійної роботи магістрантів, їх якісної самоосвіти;

- використовувати усі наявні можливості сучасних IКТ в освітньому процесі магістрантів 3 перспективою на подальшу майбутню педагогічну діяльність;

- використовувати новітні можливості технологій віртуальної реальності, мультимедіа, гіпертекстових і гіпермедійних навчальних систем;

- здійснювати незалежну і об'єктивну діагностику навчальних досягнень магістрантів, їх потенційних можливостей як викладачів 3ВО;

- оцінювати з високою часткою об'єктивності результатів навчання магістрантів згідно вимог Державного освітнього стандарту;

- здійснювати управління освітнім процесом магістрантів адекватно особливостям прояву його мотивації до педагогічної діяльності;

- створити інтерактив для постійного спілкування магістрантів і науково-педагогічних кадрів університету, націленого на підвищення ефективності освітнього процесу в магістратурі [1].
У процесі педагогічної діяльності за спеціальністю 076 Підприємництво, торгівля та біржова діяльність нами розроблено презентації та творчі завдання до різних тем з дисципліни “Технології” (модуль “Підприємництво”). Зокрема, “Особливості організації підприємницької діяльності”, “Види підприємств”, “Конкуренція й монополія" та ін.

Висновки. Таким чином, нами вивчено стан досліджуваної проблеми у науковій літературі; 3'ясовано особливості підготовки магістрів у закладах вищої освіти. Проаналізовано освітні програми зі спеціальності Підприємництво, торгівля та біржова діяльність. 3'ясовано напрями підготовки за поділом освітніх програм (дослідницькі, професійні, кар'єрні). Особлива увага закцентована на підготовці фахівців дослідницького напряму. Проаналізовано зміст педагогічної практики цієї спеціальності, що має місце в окремих закладах вищої освіти. Запропоновано окремі інноваційні методи викладання, що, за дослідженнями автора, є ефективними.

Перспективу подальшого дослідження вбачаємо в обгрунтуванні моделі формування професійної компетентності у майбутніх фахівців 3 підприємництва, торгівлі та біржової діяльності в системі ступеневої освіти.

\section{ЛІТЕРАТУРА}

1. Жукова В. М. Використання електронних навчальних комплексів у професійній підготовці та самостійній діяльності майбутніх інженерів. Вісник Луганського нац. у-ту ім. Тараса Шевченка. Педагогічні науки. 2013. №18 (1). С.68-76.

2. Закон України "Про освіту” від 05.09.2017 № 2145-VIII. URL: https://zakon.rada.gov.ua/laws/ show/2145-19 (дата звернення: 15.06.2019).

3. Міністерство освіти і науки України. Наказ №99 від 10.02.2019 р. Про Концепцію організації підготовки магістрів в Україні. URL: https:// zakon.rada.gov.ua/rada/show/v0099290-10 (дата звернення: 15.06.2019)

4. Момот О. В. Підготовка майбутніх викладачів вищих навчальних закладів до педагогічної діяльності в умовах магістратури : дис.... к. пед. н. спец.: 13.00.04 теорія і методика професійної освіти. Полтава. 2016. 311 с

5. Нагаєв В. М. Методика викладання у вищій школі : Навч. посібник. Київ, 2007. 232 с.

6. Педагогічна практика. Програма і методичні вказівки. Для студентів освітньо-кваліфікаційного рівня “магістр" денної (заочної) форм навчання спеціальності 076 Підприємництво, торгівля та біржова діяльність, спеціалізація "Управління 
персоналом та економіка праці”/ укладач Завадяк Р. I. Ужгород, $2018 \mathrm{p}$.

7. Погоріла С. Г. Основні шляхи вдосконалення професійно-педагогічної підготовки майбутніх магістрів з економіки і підприємництва у ВНЗ. Вісник національного авіаційного університету. Серія: Педагогіка, психологія №5, 2014. URL: http:/ /jrnl.nau.edu.ua/index.php/VisnikPP/article/view/ 10175/13378 (дата звернення: 14.06.2019)

8. Про затвердження Ліцензійних умов провадження освітньої діяльності Документ 11872015-П, від 23.05.2018 URL: https:// zakon.rada.gov.ua/laws/show/1187-2015-\%D0\%BF (дата звернення: 16.06.2019)

\section{REFERENCES}

1. Zhukova, V. M. (2013). Vykorystannya elektronnyh navchalnyh kompleksiv u profesinij pidgotovci ta samostijnij diyalnosti majbutnih inzheneriv [Usage of electronic training complexes in the professional training and independent work of future engineers]. Journal of State Institution "Luhansk Taras Shevchenko National University". Pedagogical sciences. No.18 (1). pp. 68-76. [in Ukrainian].

2. Zakon Ukrayiny "Pro osvitu" [The Law of Ukraine "On Education"] dated September 5, 2017 No. 2145-VIII. URL: https://zakon.rada.gov.ua/laws/ show/2145-19. [in Ukrainian].

3. Ministerstvo osvity i nauky Ukrayiny. Nakaz 99 vid 10.02.2019 p. Pro Koncepciyu organizaciyi pidgotovky magistriv v Ukrayini [About the Concept of Masters Training in Ukraine]. Available at: https:/ /zakon.rada.gov.ua/rada/show/v0099290-10 [in Ukrainian].
4. Momot, O. V. (2016). Pidgotovka majbutnih vykladachiv vyshhyh navchalnyh zakladiv do pedagogichnoyi diyalnosti $\mathrm{v}$ umovah magistratury [Future Instructorsj Training for Master-Level Teaching]. Candidate's thesis. Poltava, 311 p. [in Ukrainian].

5. Nagayev, V. M. (2007). Metodyka vykladannya u vyshhij shkoli [Methodology of Teaching in Higher Education].Teaching. manual. Kyiv, 232 p. [in Ukrainian].

6. Pedagogichna praktyka (2018). Programa i metodychni vkazivky [Pedagogical practice. Program and methodical instructions. For students of educational qualification level "master" forms of studying specialty 076 Entrepreneurship, trade and exchange activities, specialization "Personnel management and labor economics”]. (Ed.). Zavadyak R.I. Uzhgorod. [in Ukrainian].

7. Pogorila, S. H. (2014). Osnovni shlyaxy vdoskonalennya profesijno-pedagogichnoyi pidgotovky majbutnix magistriv z ekonomiky i pidpryyemnycztva $\mathrm{u}$ VNZ [Basic ways to improve the professionalpedagogical training of future masters in economics and entrepreneurship in universities]. Journal of the National Aviation University. Series: Pedagogy, Psychology. No.5. Available at: http://jrnl.nau.edu.ua/ index.php/VisnikPP/article/view/10175/13378 [in Ukrainian].

8. Pro zatverdzhennya Licenzijnyx umov provadzhennya osvitnoyi diyalnosti [About the approval of Licensing conditions for conducting educational activities]. 1187-2015-p, 23.05.2018. Available at: https://zakon.rada.gov.ua/laws/show/ $1187-2015-\%$ D0\%BF [in Ukrainian].

Стаття надійшла до редакції 20.06.2019

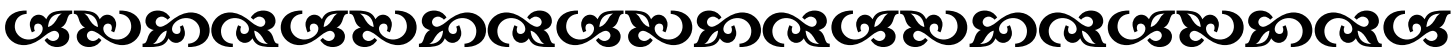
джерела”.

“Знання - настільқи дорогоиінна річ, що їх варто здобувати з будь-якого Абу-ль-ФараджМар-Тіварвіз Юхан Бар-Ебрей видатний сирійський вчений- енциклопедист

“Ттрагніть не до успіху, а до йіностей, яқі він дає”.

Альберт Ейнштейн один з найвизначніших боізиқів ХХ століття

“Науқа - це організовані знання, мудрість - це організоване життя".

Іммануӥл Кант німещький ббілособб

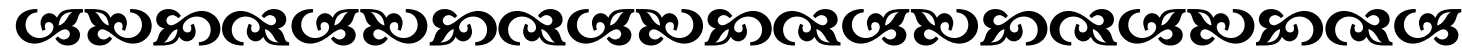

